\title{
Construction and Validity of an Instrument to Evaluate Renewable Energies and Energy Sustainability Perceptions for Social Consciousness
}

\author{
Adán Acosta-Banda ${ }^{1, *}$, Verónica Aguilar-Esteva ${ }^{2}$, Miguel Patiño Ortiz ${ }^{1}$ and Julián Patiño Ortiz ${ }^{1}$ \\ 1 Instituto Politécnico Nacional, C.P. 07738. CDMX Mexico City, Mexico; mpatino2002@ipn.mx (M.P.O.); \\ jpatinoo@ipn.mx (J.P.O.) \\ 2 Department of Design Engineering, Universidad del Istmo, C.P. 70760. Oaxaca, Mexico; \\ verodemygut@gmail.com \\ * Correspondence: adan.acosta.b@gmail.com
}

Citation: Acosta-Banda, A.; Aguilar-Esteva, V.; Patiño Ortiz, M.; Patiño Ortiz, J. Construction and Validity of an Instrument to Evaluate Renewable Energies and Energy Sustainability Perceptions for Social Consciousness. Sustainability 2021, 13, 2333. https://doi.org/10.3390/ su13042333

\section{Academic Editors:}

Samuel Asumadu-Sarkodie and Antonio Boggia

Received: 27 December 2020

Accepted: 17 February 2021

Published: 21 February 2021

Publisher's Note: MDPI stays neutral with regard to jurisdictional claims in published maps and institutional affiliations.

Copyright: (c) 2021 by the authors. Licensee MDPI, Basel, Switzerland. This article is an open access article distributed under the terms and conditions of the Creative Commons Attribution (CC BY) license (https:/ / creativecommons.org/licenses/by/ $4.0 /)$.

\begin{abstract}
The construction and content validity of an instrument to evaluate the perception and social consciousness on renewable resources and energy sustainability was done. First, a review and analysis of the existing instruments in the literature was carried out. The instrument was constructed, then reviewed by three experts, and submitted to the judgment of nine experts. Finally, it was applied to a group of twenty people to evaluate instruction and question accuracy. The instrument is integrated with four dimensions: knowledge on renewable energy; the perception of benefits obtained from it; willingness to acquire renewable energy equipment and evaluation of the use of wind and solar energies importance; the degree of personal and social awareness on environmental care as well as information on specific habits on how important it is to promote and practice energysaving and environmental sustainability. The experts' revision process resulted in the approval of the instrument. Content validity (Aiken's V > 0.75; VI > 0.50) was confirmed. The results of the pilot sample showed a favorable opinion, the understanding of the instructions and items, and the attainment of an optimal value in reliability (Cronbach's alpha: 0.8553 ). It was concluded that the instrument is valid to evaluate the perception and degree of consciousness on renewable energies and energy sustainability constructs.
\end{abstract}

Keywords: content validity; energy consciousness; renewable energies; sustainability

\section{Introduction}

Although the use of conventional energy has contributed to impressive progress in the world, it has also produced damage to the environment due to the polluting emissions produced by its use [1,2]. That is one of the main reasons why current scientific research has focused on finding different ways to conceive and carry out actions in favor of a more sustainable world [3-5]. Based on this, environmental measures, as well as international agreements which focus on strengthening good practices in the promotion of energy efficiency, have been developed in the energy sector [6-8]. There are interesting examples of scientific research that focus on finding better ways to produce energy while minimizing the ecological impact related to hydropower [9-11], solar energy [12,13], wind power [14], and biomass [15]. Moreover, the political will and the promotion of investment plans for sustainable development by companies have triggered an increasingly important role in renewable energies [16]. In addition, knowledge of theoretical and technical aspects is important for its implementation.

The knowledge of renewable energies and existing environmental problems gives guidance to individuals in society to carry out conscious actions that help preserve the environment. Understanding habitual behaviors and their impact on energy consumption, in addition to societal awareness and perceptions of renewable energy sources, is critical 
if we want to take the correct actions to prevent greater deterioration of our planet. For example, the awareness acquired for the use of ecological products, and the saving of energy and water [17]. Various authors indicate that evaluating the perception of renewable energies provides the basis for investigating the degree of knowledge that the inhabitants have about renewable energies $[18,19]$. In fact, these authors present the main opinions of the social agents and their perspectives regarding the adoption of renewable energies, providing the elements to understand the current social situation regarding the issue.

There are various contributions that study the perception of energy and environmental sustainability. In [18] a confirmatory validation of the scales given to the "ecological behavior components" and the "components of the attitudes of an ecological consumer" was done, in order to contribute to the comprehension of the psychological relation between attitudes toward behavior in relation to ecological sustainability. In [20] the ecological behavior was studied by observing the "degree of pro-environmental behavior" based on "pro-ecological behavior" measures and resulted in the generation of formative knowledge and sustainable coexistence schemes. In [21] the social perceptions of renewable energies were studied and analyzed, yielding evidence of the need to promote the use and implementation of renewable energies throughout the world. The literature also addresses factors such as: (a) participation, (b) communication, and (c) negotiation; and in conflicts related to energy and the environment, it highlights aspects of the public perception of energy and the factors that condition it [22]. In [23] the social perception of the implementation of renewable energy in industrial processes is studied. The report of an analysis of the intervention of social perception for the feasibility in the energy transition based on renewable technology stands out, highlighting categories focused on technical and environmental knowledge, evaluating the advantage and appropriation of new technologies [24]. In [25] the conclusions show that it is possible to successfully promote the adoption of clean technology by intensely competitive, informal firms, even when the new technology significantly increases variable costs. Further, community pressure applied by competing firms and local private sector organizations can generate incentives for adoption. Likewise, in [26] activities to strengthen sustainable environmental education are highlighted, generally engaging the collaboration of all sectors of society for the construction of a sustainable community.

It is important to address the bases of this knowledge from various models of behavioral change [27-30]. The theory of reasoned action is highlighted [31,32], posing a series of observations to optimize the results of proposals made by the researchers in order to explain and predict behaviors. It is important to analyze the factors of behavior that favor the environment and the implications that they have. One of the models proposed for this purpose is that of rationally limited choice, which leaves room for individual values and social influences in a construction process of preferences. This model is consistent with the nature of human cognitive abilities [33,34]. In this same sense, Stern, Dietz, and Guagnano [35] studied the scale of new ecological paradigms from variables in a theoretical model of environmental concern.

Some of the methodologies used by researchers to explore perceptions related to energy, environment, and sustainability, as well as their behavior, were analyzed, thus a brief description of what was found in the literature is summarized in this paragraph. In reference to the above, the individual attitude towards the environment [18] is investigated with the Likert-type methodology integrating cognitive, affective, and conative factors to improve the understanding of ecological behavior. Matos, Pasek, Peña, and Briceño [26] also promoted methodologies by designing interviews and questionnaires with Likerttype responses. In a similar way, Barrera, Ocaña, Sotelo, and Echeverría [20] designed an instrument composed of four categories. The research done in [21] describes a survey made up of two sections: the first collected sociodemographic information and the second section is made up of 12 items that reflect preferences regarding the need to promote the use and implementation of renewable energies in respect to their installation and development. In [22] an analysis is presented through semi-structured interviews aimed at the social actors that participate in wind projects, analyzing the diversification of social actors in 
decision-making related to science, technology, and the environment. The survey designed in [23] facilitates a greater public understanding of renewable energy in industrial processes. In [24] the design of an instrument that assesses the social interrelations and the structuring of the environmental and economic perception in order to understand the perceptions of feasibility in the implementation of renewable energies is highlighted.

As we've seen, evaluating theoretical aspects, perceptions, and interests of renewable energies, as well as aspects of environmental sustainability, is useful for understanding behavior and can provide the basis for the development of strategies to change the population's attitude towards these issues. Another aspect to be pointed out is the few methodological antecedents that exist for the design of instruments with the purpose of evaluating the general knowledge of renewable energies. It is important to mention that there are few methodologies that have gone through a process of review and expert judgment. To illustrate, the proposal by Muñoz et al. [23] explains the expert review and expert judgment processes. The expert review shows prima facie validity, which aims to measure something specifically, verify the questions or items pertaining to the phenomenon or construct, its relevance, and the writing [36], while the expert judgment is defined as an informed opinion of people with a background in the subject who can give information, judgments and evaluations [37]. Its function is to determine the validity of the instrument's content, specifically to ensure the correspondence of the items of each category with the construct to which they belong.

Given the importance of the issue of energy and sustainability, there is a great need to understand the behavior of society while facing the challenge of migrating towards the use and exploitation of renewable energies [38]. For this reason, the objectives of this research were: (a) to design an instrument that integrates the pertinent and relevant dimensions in regards to theoretical aspects of energy efficiency, wind, and solar energy perception, individual and social interest of environmental care, and environmental sustainability; (b) to validate the content of the instrument proposed; (c) to validate the factors and theoretical model of the instrument proposed. All of the specific objectives listed can be condensed into a general one: to construct and validate a feasible instrument to obtain important information regarding environmental care and energy efficiency from the perception of the individuals in society. The design of the instrument proposed in this article was submitted to an expert review and an expert judgment in order to analyze whether it has prima facie and content validity. The importance of this research lies in the fact that there are few instruments that provide valid information for the evaluation of perception, knowledge, and behavior associated with the habits of the population regarding energy efficiency and ecological sustainability.

\section{Materials and Methods}

This investigation consisted of an instrumental study aimed at the development of tests and devices, including design, such as the study/analysis of psychometric properties [39] as shown in Figure 1. 


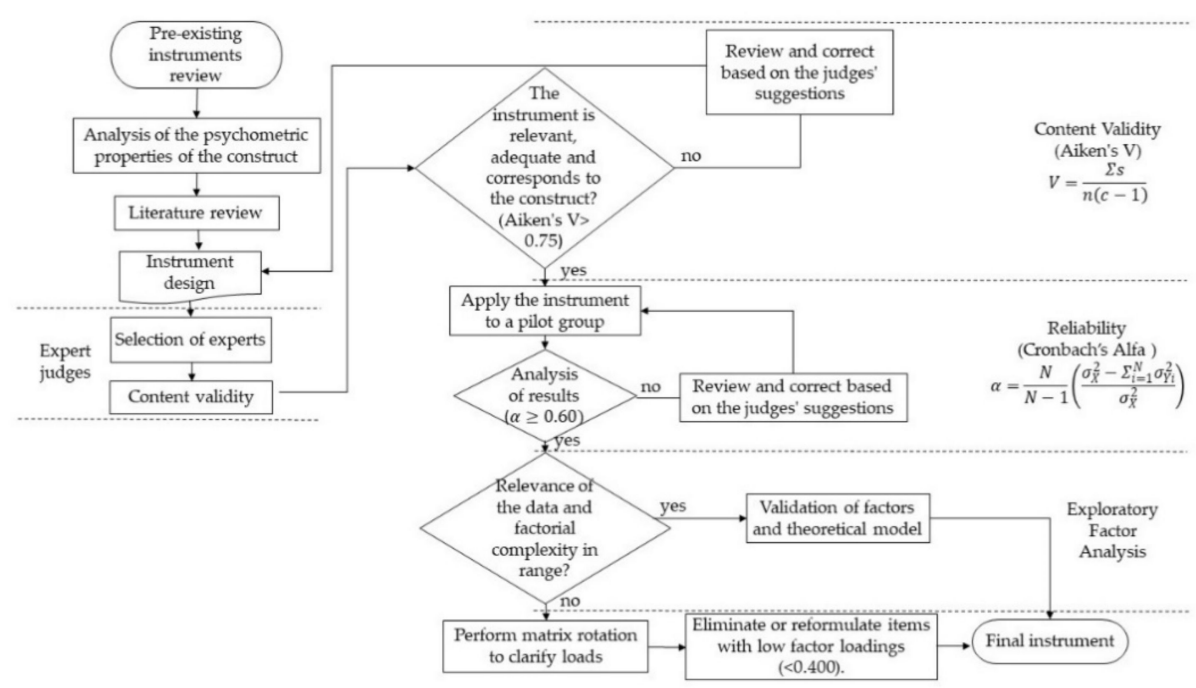

Figure 1. Methodology flow chart.

The first phase consisted of revising the advance in the literature regarding this topic and the study of pre-existing methods and tools that analyze the psychometric properties of the construct. For content validity, the instrument was reviewed by a core of expert judges who evaluated each of the items. According to the literature, an instrument is valid if the experts evaluate the items as relevant, proper, and corresponding to the construct. To make sure the evaluations achieve a high-quality metric, the Aiken $[40,41]$ index was applied to the numeric evaluation from the expert judges with the following Equation (1).

$$
V=\frac{\Sigma s}{n(c-1)} .
$$

where:

$V=$ item validity index;

$s=$ scores assigned by each rater minus the lowest score in the used category $(\mathrm{s}=\mathrm{r}-\mathrm{lo}$, with $\mathrm{r}=$ rater category selection score and $\mathrm{lo}=$ the lowest scores in the scoring category);

$n=$ number of raters and;

$c=$ number of categories that raters can choose.

In addition, the methodology to analyze the construct validity of the instrument consisted in getting an answer to the instrument from a sample of twenty people, then analyzing the values obtained with Cronbach's alpha $(\alpha)$ [42,43], which measures the extent to which the item responses (answers to survey questions) correlate with each other. In other words, $\alpha$ estimates the proportion of variance that is systematic or consistent in a set of survey responses. The general formula to calculate Cronbach's alpha is shown in Equation (2).

$$
\alpha=\frac{N}{N-1}\left(\frac{\sigma_{X}^{2}-\Sigma_{i=1}^{N} \sigma_{Y i}^{2}}{\sigma_{X}^{2}}\right) .
$$

where:

$N=$ the number of survey items in the scale;

$\sigma_{X}^{2}=$ the variance of the observed total scores;

$\sigma_{Y i}^{2}=$ the variance of item $i$ for person $Y$.

\subsection{Proposed Instrument}

Based on the literature review and antecedents found [18,35], the dimensions that make up the instrument were postulated. The objective of the instrument is to evaluate the 
following dimensions: theoretical aspects; wind and solar energy perception; individual and social interest of environmental care; environmental sustainability (Table 1).

Table 1. Renewable energy and environmental sustainability (REES).

\begin{tabular}{|c|c|}
\hline Dimensions & Instrument Questions \\
\hline 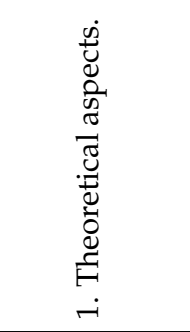 & $\begin{array}{l}\text { 1. What is your degree of knowledge regarding renewable energy? } \\
\text { 2. What is your degree of knowledge regarding wind energy? } \\
\text { 3. What is your degree of knowledge regarding a wind turbine? } \\
\text { 4. What is your degree of knowledge regarding solar energy? } \\
\text { 5. What is your degree of knowledge regarding a solar panel? } \\
\text { 6. What is your degree of knowledge regarding biomass energy? } \\
\text { 7. What is your degree of knowledge regarding hydraulic energy? } \\
\text { 8. What is your degree of knowledge regarding energy and environmental sustainability? }\end{array}$ \\
\hline 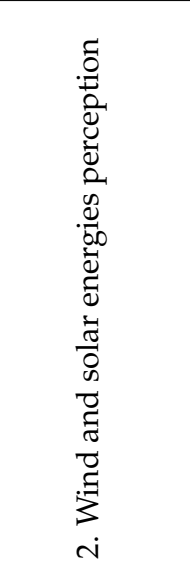 & $\begin{array}{l}\text { 9. Wind and solar energy are sources of clean and inexhaustible electricity generation. } \\
\text { 10. If wind turbines are used in all regions of the world to generate electricity, the planet } \\
\text { will be greatly benefited. } \\
\text { 11. If companies and/or governments invest in installing wind farms, you will be benefited. } \\
\text { 12. Buying a small wind turbine for your home will be expensive. } \\
\text { 13. If the government gave you a wind turbine, you would accept it and use it. } \\
\text { 14. Buying a small wind turbine for your home will contribute to caring for the } \\
\text { environment, while reducing electricity costs and promoting better social conditions. } \\
\text { 15. If solar panels are used in all regions of the world to generate electrical energy, the } \\
\text { planet will be greatly benefited. } \\
\text { 16. If companies and/or governments invest in installing solar parks, you will be benefited. } \\
\text { 17. Buying a solar panel for your home will be very expensive. } \\
\text { 18. If the government gave you a solar panel, you would accept it and use it. } \\
\text { 19. Buying a solar panel for your home will contribute to the care of the environment and } \\
\text { savings in the cost of electrical energy. }\end{array}$ \\
\hline 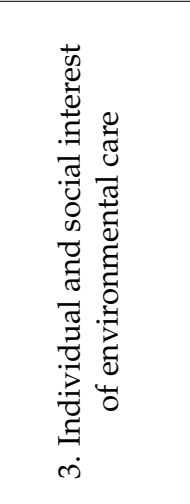 & $\begin{array}{l}\text { 20. In general, society is strongly interested in: taking care of the environment and related } \\
\text { topics. } \\
\text { 21. Every day I carry out concrete actions to reduce ecological damage and energy } \\
\text { consumption. } \\
\text { 22. Climate change is largely due to the fact that humans have not adequately cared for the } \\
\text { environment. } \\
\text { 23. The authorities are very interested in promoting environmental care in society. } \\
\text { 24. There is an initiative in society to organize and carry out actions in favor of caring for } \\
\text { the environment. } \\
\text { 25. Companies are very interested in participating with society to support the care of the } \\
\text { environment. } \\
\text { 26. It is very important to meet present needs without compromising the ability to meet the } \\
\text { essential needs of future generations. }\end{array}$ \\
\hline 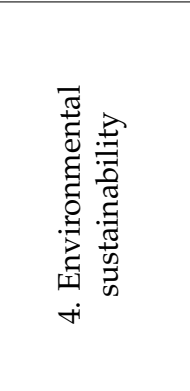 & $\begin{array}{l}\text { 27. How often do you buy energy-efficient light bulbs to light up your home? } \\
\text { 28. How often do you turn off the light when you leave a room, which will be left empty? } \\
\text { 29. How often do you turn off or suspend your computer when you stop using it? } \\
\text { 30. How often do you leave your television on even when you are not watching it? } \\
\text { 31. How often do you disconnect all electrical appliances that do not require to be } \\
\text { 32. How often do you collaborate by watering a plant or a tree at home, work, or school? } \\
\text { 33. How often do you use recyclable bags when shopping? } \\
\text { 34. How often do you practice the "lather up-water off" advice when showering to save } \\
\text { water? }\end{array}$ \\
\hline
\end{tabular}

\subsection{Expert Review and Content Validity Study by Expert Judgment}

The instrument was submitted to the review of three experts with professional trajectories in the writing of instruments to assess the belonging to the construct and viability of 
the elements proposed, in order to verify the relevance of the dimensions and items. The data of the sociodemographic factors are displayed in Table 2.

Table 2. Sociodemographic data of experts and expert judges.

\begin{tabular}{|c|c|c|}
\hline Indicator & Experts & Expert Judges \\
\hline \multirow{2}{*}{ Gender (\%) } & Men: $66.6 \%$ & Men: $77 \%$ \\
\hline & Women: $33.6 \%$ & Women: $23 \%$ \\
\hline \multirow{3}{*}{ Last level of study (\%) } & Master's: $0 \%$ & Master's: $66 \%$ \\
\hline & Doctorate: $100 \%$ & Doctorate: $33 \%$ \\
\hline & Post-doctorate: $0 \%$ & Post-doctorate: $0 \%$ \\
\hline \multirow{2}{*}{ Areas of professional experience (\%) } & Technology: $0 \%$ & Technology: $33.30 \%$ \\
\hline & Teaching: $100 \%$ & Teaching: $66.70 \%$ \\
\hline $\begin{array}{l}\text { Number of years of professional experience } \\
\text { (Mean }+ \text { standard deviation) }\end{array}$ & $28.6+10.1$ & $20+9.6$ \\
\hline $\begin{array}{l}\text { Number of years of teaching-research experience } \\
\text { (Mean + standard deviation) }\end{array}$ & $13+4.35$ & $11.22+3.45$ \\
\hline $\begin{array}{l}\text { Number of articles published } \\
\text { (Mean + standard deviation) }\end{array}$ & $9.6+9.1$ & $7.66+9.93$ \\
\hline $\begin{array}{l}\text { Number of books published } \\
\text { (Mean }+ \text { standard deviation) }\end{array}$ & $0.33+0.57$ & $0.44+0.72$ \\
\hline $\begin{array}{l}\text { Number of papers published in conference } \\
\text { proceedings or minutes books and scientific events } \\
\text { (Mean }+ \text { standard deviation) }\end{array}$ & $6+3.6$ & $9.55+13.57$ \\
\hline $\begin{array}{l}\text { Experience in reviewing, designing, and/or } \\
\text { validating research instrument }(\%)\end{array}$ & $100 \%$ & $100 \%$ \\
\hline
\end{tabular}

The content validity study was carried out through the judgment of nine experts (Table 2), who were chosen using the criteria of: knowledge and experience on the subject; effective communication capacity and impartiality; inherent qualities such as confidence in him/herself, and adaptability [44]. The trial had a qualitative-quantitative approach through which the relevance and wording of the items were evaluated. The qualitative evaluation was derived from the structuring of the domain and the degree of belonging of the items to each of the categories. For the quantitative evaluation, two routes were used: the first was that the judges evaluated the relevance and wording of the proposed dimensions using a scale made up of 4 levels (low, acceptable, good, and excellent) and the analysis of these results was carried out using percentage response frequencies; the second way was the evaluation of the relevance and writing of the items and descriptors, for which the Likert scale of expert judges ( 1 to 4 ) was used. After obtaining the evaluation by the judges, the content validity coefficient Aiken's V [41] and its 99\% confidence interval were calculated. For the coefficient, an accepted value of greater than 0.75 was stipulated [45] and greater than 0.50 for the lower value of the interval [46].

Additionally, an exploratory factor analysis (EFA) was carried out, considering the relevance of the data with the Kaiser Meyer Olkin (KMO) and Bartlett tests. Once the assumptions of the method were verified, the factor analysis was carried out with the principal axis factorization method [47]. It is important to highlight that the choice of the number of factors to retain was considered with the Gutman-Kaiser rule and the percentage of the variance explained. If the factorial matrix presents items with significant factor loadings to more than one factor, the rotation of the matrix is done using the most convenient algorithm [48]. 


\subsection{Pilot Test Application}

A pilot test of the instrument was carried out on a group of twenty people using an electronic form. The objective of this phase was to carry out an initial reliability analysis using Cronbach's alpha [42] and to evaluate the clarity of the instructions and questions using the instrument satisfaction questionnaire.

\subsection{Methodology Limitations}

There are some limitations concerning the sample of the study. The information collected through the instrument in this phase was obtained from a sample described in Table 2. The sample consisted of experts whose cultural background belongs to a Mexican type and from an educational level that is not the common one. As shown in this table, $66 \%$ have master's degrees and 33\% have doctorates. For a first approach in the validation of an instrument, these results are valuable. However, it is necessary to invite other groups of researchers to apply the instrument to people living in different regions of the world, and to use this instrument in further investigations to compare the results and get new conclusions.

\section{Results}

\subsection{Expert Review and Expert Judgment}

The expert's phase improved the instrument's quality, specifically: some grammatical and spelling errors as well as the adjustment of some answer descriptors. The expert judges stage provided important suggestions through the quantitative evaluation in order to improve the wording and clarify the relevance of each of the items. The expert judges' evaluation of the relevance and wording of the proposed dimensions can be observed in Table 3.

Table 3. Relevance and writing quality percentage results obtained from expert judges.

\begin{tabular}{ccccccccc}
\hline \multirow{2}{*}{ Dimensions } & \multicolumn{4}{c}{ Relevance } & \multicolumn{3}{c}{ Writing Quality } \\
\cline { 2 - 10 } & Low Level & $\begin{array}{c}\text { Acceptable } \\
\text { Level }\end{array}$ & $\begin{array}{c}\text { Good } \\
\text { Level }\end{array}$ & $\begin{array}{c}\text { Excellent } \\
\text { Level }\end{array}$ & Low Level & $\begin{array}{c}\text { Acceptable } \\
\text { Level }\end{array}$ & $\begin{array}{c}\text { Good } \\
\text { Level }\end{array}$ & $\begin{array}{c}\text { Excellent } \\
\text { Level }\end{array}$ \\
\hline 1. & - & $7.66 \%$ & $24.44 \%$ & $68.14 \%$ & - & $7.40 \%$ & $23.70 \%$ & $68.51 \%$ \\
\hline 2. & - & $8.11 \%$ & $24.46 \%$ & $67.27 \%$ & - & $11.49 \%$ & $20.57 \%$ & $68.29 \%$ \\
\hline 3. & $7.11 \%$ & - & $24.44 \%$ & $68.44 \%$ & $5.05 \%$ & $5.05 \%$ & $20.50 \%$ & $67.55 \%$ \\
\hline 4. & - & - & $22.61 \%$ & $77.39 \%$ & - & $11.11 \%$ & $33.33 \%$ & $55.55 \%$ \\
\hline
\end{tabular}

The quantitative evaluation by the expert judges can be observed in Table 4 . The items were validated in terms of relevance, obtaining values higher than the minimum established in the coefficient used (Aiken's V > 0.75; VI > 0.50). Regarding the evaluation of the wording, acceptable and higher-than-recommended values were obtained for most of the items (Aiken's V > 0.75; VI > 0.50). However, for items 10,17, and 23, the values obtained were lower than the permissible ones (Aiken's $\mathrm{V}<0.75 ; \mathrm{VI}<0.50$ ), therefore, these were reviewed and improved with the judges' suggestions. In this regard, the grammar and syntax were corrected. 
Table 4. Results of the calculation of Aiken's V and 99\% confidence interval for the relevance criteria and writing of items and descriptors.

\begin{tabular}{|c|c|c|c|c|c|c|}
\hline \multirow{2}{*}{ Ítem } & \multirow{2}{*}{$\begin{array}{c}\text { Relevance/Pertinence } \\
\text { Aiken's V }\end{array}$} & \multicolumn{2}{|c|}{ IC $99 \%$} & \multirow{2}{*}{$\begin{array}{c}\text { Writing } \\
\text { Aiken's V }\end{array}$} & \multicolumn{2}{|c|}{ IC $99 \%$} \\
\hline & & Lower Value & Top Value & & Lower Value & Top Value \\
\hline 1 & 0.852 & 0.647 & 0.948 & 0.852 & 0.647 & 0.948 \\
\hline 2 & 0.926 & 0.737 & 0.982 & 0.926 & 0.737 & 0.982 \\
\hline 3 & 0.889 & 0.691 & 0.966 & 0.889 & 0.691 & 0.966 \\
\hline 4 & 0.852 & 0.647 & 0.948 & 0.852 & 0.647 & 0.948 \\
\hline 5 & 0.926 & 0.737 & 0.982 & 0.926 & 0.737 & 0.982 \\
\hline 6 & 0.889 & 0.691 & 0.966 & 0.852 & 0.647 & 0.948 \\
\hline 7 & 0.889 & 0.691 & 0.966 & 0.889 & 0.691 & 0.966 \\
\hline 8 & 0.889 & 0.691 & 0.966 & 0.889 & 0.691 & 0.966 \\
\hline 9 & 0.852 & 0.647 & 0.948 & 0.815 & 0.605 & 0.927 \\
\hline 10 & 0.852 & 0.647 & 0.948 & 0.704 & 0.489 & 0.855 \\
\hline 11 & 0.926 & 0.737 & 0.982 & 0.926 & 0.737 & 0.982 \\
\hline 12 & 0.815 & 0.605 & 0.927 & 0.815 & 0.605 & 0.927 \\
\hline 13 & 0.889 & 0.691 & 0.966 & 0.889 & 0.691 & 0.966 \\
\hline 14 & 0.926 & 0.737 & 0.982 & 0.926 & 0.737 & 0.982 \\
\hline 15 & 0.926 & 0.737 & 0.982 & 0.926 & 0.737 & 0.982 \\
\hline 16 & 0.963 & 0.787 & 0.995 & 0.963 & 0.787 & 0.995 \\
\hline 17 & 0.778 & 0.565 & 0.904 & 0.704 & 0.489 & 0.855 \\
\hline 18 & 0.926 & 0.737 & 0.982 & 0.926 & 0.737 & 0.982 \\
\hline 19 & 0.963 & 0.787 & 0.995 & 0.963 & 0.787 & 0.995 \\
\hline 20 & 0.889 & 0.691 & 0.966 & 0.889 & 0.691 & 0.966 \\
\hline 21 & 0.963 & 0.787 & 0.995 & 0.963 & 0.787 & 0.995 \\
\hline 22 & 0.926 & 0.737 & 0.982 & 0.926 & 0.737 & 0.982 \\
\hline 23 & 0.778 & 0.565 & 0.904 & 0.667 & 0.45 & 0.829 \\
\hline 24 & 0.926 & 0.737 & 0.982 & 0.889 & 0.691 & 0.966 \\
\hline 25 & 0.926 & 0.737 & 0.982 & 0.926 & 0.737 & 0.982 \\
\hline 26 & 0.815 & 0.605 & 0.927 & 0.815 & 0.605 & 0.927 \\
\hline 27 & 0.926 & 0.737 & 0.982 & 0.926 & 0.737 & 0.982 \\
\hline 28 & 0.963 & 0.787 & 0.995 & 0.963 & 0.787 & 0.995 \\
\hline 29 & 0.963 & 0.787 & 0.995 & 0.963 & 0.787 & 0.995 \\
\hline 30 & 0.963 & 0.787 & 0.995 & 0.963 & 0.787 & 0.995 \\
\hline 31 & 0.963 & 0.787 & 0.995 & 0.963 & 0.787 & 0.995 \\
\hline 32 & 0.778 & 0.565 & 0.904 & 0.815 & 0.605 & 0.927 \\
\hline 33 & 0.852 & 0.647 & 0.948 & 0.815 & 0.605 & 0.927 \\
\hline 34 & 0.889 & 0.691 & 0.966 & 0.926 & 0.737 & 0.982 \\
\hline
\end{tabular}

Once the instrument had been evaluated by the expert judgment group and satisfactory values had been obtained, the relevance of the data was verified and then analyzed by the EFA (KMO: 0.816; Bartlett's test: $2632 \mathrm{gl}: 351 ; p<0.001)$. The analysis revealed four factors that corresponded to the theoretical model that was proposed, explaining more 
than $42 \%$ of the variance. However, five items presented factorial complexity, which is why the matrix was rotated to clarify the loads (Table 5).

Table 5. Matrix rotation.

\begin{tabular}{|c|c|c|c|c|}
\hline Item & Factor 1 & Factor 2 & Factor 3 & Factor 4 \\
\hline 1 & 0.69 & & & \\
\hline 2 & 0.745 & & & \\
\hline 3 & 0.769 & & & \\
\hline 4 & 0.667 & & & \\
\hline 5 & 0.666 & & & \\
\hline 6 & 0.665 & & & \\
\hline 7 & 0.71 & & & \\
\hline 8 & 0.593 & & & \\
\hline 9 & & 0.534 & & \\
\hline 10 & & 0.514 & & \\
\hline 11 & & 0.638 & & \\
\hline 14 & & 0.646 & & \\
\hline 15 & & 0.71 & & \\
\hline 16 & & 0.701 & & \\
\hline 19 & & 0.7 & & \\
\hline 20 & & & 0.599 & \\
\hline 21 & & & & 0.473 \\
\hline 23 & & & 0.687 & \\
\hline 24 & & & 0.693 & \\
\hline 25 & & & 0.69 & \\
\hline 31 & & & & 0.539 \\
\hline 32 & & & & 0.468 \\
\hline 33 & & & & 0.558 \\
\hline 34 & & & & 0.71 \\
\hline
\end{tabular}

\subsection{Pilot Group}

The application of the instrument to the pilot group reflected satisfactory results, obtaining favorable opinions regarding the understanding of instructions and items. Likewise, they qualified the instrument as satisfactory. Due to the relevance of the questions, the pilot group declared them acceptable. Cronbach's alpha equal to 0.8553 was obtained from the initial reliability analysis carried out on the entire bank of elements. Next, a reliability analysis of each of the four proposed constructs was performed, obtaining the following results: theoretical aspects (Cronbach's alpha $=0.8680$ ); perception of wind and solar energy (Cronbach's alpha $=0.6420)$; personal and collective interest of the environment (Cronbach's alpha $=0.7578)$; environmental sustainability $($ Cronbach's alpha $=0.7800)$.

\section{Discussion and Conclusions}

The study of perceptions may help us to understand the behavior of people towards environmental issues. In [49] the conclusions show that the evaluation of general concern for the environment is a predictor for the concern of the environment, but it is not a predictor of conducts, values, or other pro-environmental thoughts. In the instrument proposed in this paper, the aim is to look forward to correlating the perceptions and the habits expressed by the people surveyed. Knowledge of energy perception and awareness regarding renewable energies, energy itself, and environmental sustainability are relevant aspects that allow us to understand the relationship that the population has with renewable energies and the environment as well as to understand their behavior. In this sense, the instrument described in this document represents a contribution to the subject because it helps us understand the knowledge level that the population has about renewable energies and, additionally, the perception and awareness that exists in relation to those energies. It 
also allows us to obtain information on the specific habits of the population in relation to the degree of awareness regarding energy efficiency and environmental sustainability.

Specifically, the instrument, renewable energy and environmental sustainability (REES) integrates the main aspects of two of the energy sources (wind and solar) that are currently emerging through the four categories described. This allows us to understand a segment of the population's knowledge in relation to energy, to increase awareness among each respondent about energy and environmental sustainability, as well as to understand their perceptions.

The instrument was subject to a formal process of expert review, evaluation by expert judges, and pilotage. In fact, the aim of the judges' review was: (a) to determine if the dimensions and items belong and are representative of the theoretical construct to be evaluated; (b) to verify the relevance of the items [50]. According to the results, the research experts in this document evaluated the dimensions and items of the instrument, reflecting on the relevance and representation of the theoretical construct. Finally, the expert review also included suggestions regarding the writing, and these were included.

The mechanism for analyzing content validity was the judgment of experts. In [51] a clear and extended explanation on how "judgment implies using information and knowledge to form an assessment or evaluation" that is useful for scientific research is found. Specifically, for the purpose of this research, the valuable knowledge and expertise of the judges in regards to the constructs studied and used to design the instrument proposed is highly valuable, due to the fact that the type of research is related to a topic where no accuracy can be determined by numbers since psychological and behavioral factors are the most relevant in the scope of the investigation. The selection of judges, the number of judges, and the scheme implemented (qualitative-quantitative) are the most relevant factors to take into account in this phase [52-54]. The evaluation of the relevance and writing of the proposed dimensions was favorable. In the second phase, the relevance of the items was evaluated in terms of writing. Items subject to improvement were identified by expert judges (qualitative evaluation). The improvements consisted of correcting the wording and the syntax of the responses to items 10,17, and 23. After the corrections were done according to the judges' observations, the instrument presented content validity, thus indicating that the aspects selected for the preparation of the measuring instrument are indicators of what it is intended to measure.

An elemental aspect of an instrument is clarity in instruction and items and suitability for the target population $[55,56]$. For this reason, it was necessary to establish a pilot project for the instrument, and subsequently, the test was applied to a pilot group. It was verified that the instructions and items of the instrument were considered satisfactory and favorable. These aspects are important, as Haynes, Richard, and Kubany state in [57] where they explain that poor item wording or imprecise instructions are factors that threaten the validity and reliability of an instrument.

An analysis of matrix rotation was done, and items 22, 26, and 29 presented unrepresentative factor loads. Due to this, the items were not included in the final version of the instrument. The reliability of an instrument is the property that designates the constancy and precision of the results obtained when applying it on different occasions [58]. In this sense, the value that was obtained for the pilot sample was Cronbach's alpha: 0.8553, which means that the application of the instrument produces consistent and coherent results [59] and that the correlation between items and representation of the concept addressed is verified [60]. However, as Martínez [61] refers, the reliability analysis requires a sample of more than 200 participants, thus the value obtained in this research should only be taken as exploratory. In accordance with what has been previously described, it is necessary, for future investigation, that this instrument "REES" is applied to a bigger population sample since, through its application, the instrument can be evaluated for construct validity [62].

In conclusion, the objective of this instrument is the collection of reliable and timely information regarding the degree of knowledge, perception, and energy awareness of renewable energies as well as knowing the habits of the general population regarding 
energy efficiency and environmental sustainability. This research may be useful for universities, companies, scientists, and researchers as well as for civil society [63]. Once the psychometric properties analysis framework is completed and with a future application, it will allow the collection of valuable information with which it will be possible to list strategies that permit an understanding of how advanced the knowledge of advantages and disadvantages of the use of renewable energies is. In the same way, it will help us generate strategies to increase awareness of environmental protection and energy efficiency among the population [64]. In addition, it is necessary to continue promoting actions that contribute to caring for the environment and spread theoretical knowledge regarding technologies that help reduce environmental impacts. The type of instrument designed in this article invites educational institutions, governmental bodies, and communities interested in renewable energies and sustainability to answer the instrument and make a diagnostic analysis of the level of knowledge of renewable energies, their perceptions on: (a) energy efficiency and, (b) specific actions taken to reduce impacts to the environment. This information gives researchers specific data to determine the progress in energy sustainability and to propose strategies that help to achieve sustainable development goals [65].

Author Contributions: Conceptualization, A.A.-B., V.A.-E. and M.P.O.; methodology, A.A.-B., V.A.-E. and M.P.O.; software, A.A.-B. and V.A.-E.; validation, A.A.-B., M.P.O., V.A.-E. and J.P.O.; formal analysis, A.A.-B., V.A.-E. and M.P.O.; investigation, A.A.-B., V.A.-E., M.P.O. and J.P.O.; resources, A.A.B., V.A.-E., M.P.O. and J.P.O.; data curation, A.A.-B. and V.A.-E.; writ-ing-original draft preparation, A.A.-B., V.A.-E., M.P.O. and J.P.O.; writing-review and editing, A.A.-B. and V.A.-E.; visualization, A.A.-B., V.A.-E., M.P.O. and J.P.O.; supervision, A.A.-B. and M.P.O. All authors have read and agreed to the published version of the manuscript.

Funding: This research received no external funding.

Informed Consent Statement: Informed consent was obtained from all subjects involved in the study.

Data Availability Statement: Not applicable.

Conflicts of Interest: The authors declare no conflict of interest.

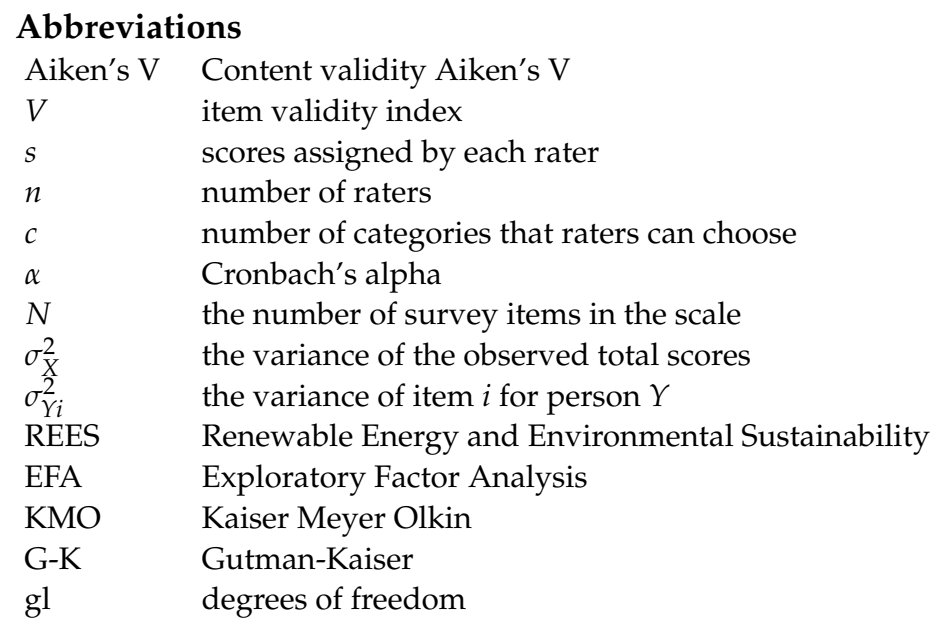

\section{References}

1. Molina, M.G.; Mercado, P.E.; Wiernes, P.E. Análisis y simulación de algoritmos de control para el seguimiento del punto de máxima potencia de sistemas solares fotovoltaicos conectados a la red eléctrica. Av. Energías Renov. Medio Ambiente 2007, 11, 153-160.

2. Zhang, Y.; Peng, C.; Guo, Z.; Xiao, X.; Xiao, R. Polycyclic aromatic hydrocarbons in urban soils of China: Distribution, influencing factors, health risk and regression prediction. Environ. Pollut. 2019, 254, 112930. [CrossRef]

3. Xia, L.-W.; Cao, J.; Wang, M.; Mi, J.-L.; Wang, T.-T. A review of carbonates as hydrocarbon source rocks: Basic geochemistry and oil-gas generation. Pet. Sci. 2019, 16, 713-728. [CrossRef]

4. Rani, P.; Mishra, A.R.; Mardani, A.; Cavallaro, F.; Alrasheedi, M.; AlRashidi, A. A novel approach to extended fuzzy TOPSIS based on new divergence measures for renewable energy sources selection. J. Clean. Prod. 2020, 257, 120352. [CrossRef] 
5. Tirapegui, W.J. Introducción a las Energías Renovables No Convencionales, 1st ed.; Libro 156.805; Fyrma: Santiago de Chile, Chile, 2006.

6. Mellit, A.; Kalogirou, S.; Hontoria, L.; Shaari, S. Artificial intelligence techniques for sizing photovoltaic systems: A review. Renew. Sustain. Energy Rev. 2009, 13, 406-419. [CrossRef]

7. Büyüközkan, G.; Güleryüz, S. An integrated DEMATEL-ANP approach for renewable energy resources selection in Turkey. Int. J. Prod. Econ. 2016, 182, 435-448. [CrossRef]

8. Kahraman, C.; Kaya, I.; Cebi, S. A comparative analysis for multiattribute selection among renewable energy alternatives using fuzzy axiomatic design and fuzzy analytic hierarchy process. Energy 2009, 34, 1603-1616. [CrossRef]

9. Kuriqi, A.; Pinheiro, A.N.; Sordo-Ward, A.; Garrote, L. Water-energy-ecosystem nexus: Balancing competing interests at a run-of-river hydropower plant coupling a hydrologic-ecohydraulic approach. Energy Convers. Manag. 2020, $223,113267$. [CrossRef]

10. Suwal, N.; Huang, X.; Kuriqi, A.; Chen, Y.; Pandey, K.P.; Bhattarai, K.P. Optimisation of cascade reservoir operation considering environmental flows for different environmental management classes. Renew. Energy 2020, 158, 453-464. [CrossRef]

11. Suwal, N.; Kuriqi, A.; Huang, X.; Delgado, J.; Młyński, D.; Walega, A. Environmental Flows Assessment in Nepal: The Case of Kaligandaki River. Sustainability 2020, 12, 8766. [CrossRef]

12. Sharif, A.; Meo, M.S.; Chowdhury, M.A.F.; Sohag, K. Role of solar energy in reducing ecological footprints: An empirical analysis. J. Clean. Prod. 2021, 292, 126028. [CrossRef]

13. Shahsavari, A.; Akbari, M. Potential of solar energy in developing countries for reducing energy-related emissions. Renew. Sustain. Energy Rev. 2018, 90, 275-291. [CrossRef]

14. Saidur, R.; Rahim, N.; Islam, M.; Solangi, K. Environmental impact of wind energy. Renew. Sustain. Energy Rev. 2011, 15, 2423-2430. [CrossRef]

15. Wang, Z.; Bui, Q.; Zhang, B.; Pham, T.L.H. Biomass energy production and its impacts on the ecological footprint: An investigation of the G7 countries. Sci. Total. Environ. 2020, 743, 140741. [CrossRef]

16. Martínez-Mendoza, E.; Rivas-Tovar, L.A.; Vera-Martínez, P.S. The wind energy between Mexico and Spain. Perf. Latinoam. 2019, $27,1-21$.

17. Izagirre-Olaizola, J.; Fernández-Sainz, A.; Vicente-Molina, M.A. Antecedentes y barreras a la compra de productos ecológicos (Background and barriers to buying organic products). Universia Bus. Rev. 2013, 38, 108-127.

18. Miguens, M.J.L.; González, P.; Álvarez Vázquez, E.G.; Rodríguez, M.J.G. Medidas del comportamiento ecológico y antecedentes. Conceptualización y validación empírica de escalas. Univ. Psychol. 2014, 14, 189-204. [CrossRef]

19. Martínez, P.; González, N. Las competencias transversales en la universidad: Propiedades psicométricas de un cuestionario (Transversal competences at university: Psychometric properties of a questionnaire). Educ. XX1 2018, 21, $231-262$.

20. Barrera, L.F.; Ocaña, J.; Sotelo, M.A.; Echeverría, S.B. Conductas sustentables en estudiantes universitarios de México (Sustainable behaviors in university students in Mexico). Atenas 2019, 45, 20-35.

21. Serrano, M.L.; Molina-Ruiz, J. La percepción social de las energías renovables a través de una encuesta de opinión. Un caso práctico en localidades del noroeste murciano (The social perception of renewable energy through an opinion poll. A case study in locations in the north west of Murcia). Pap. Geogr. 2006, 44, 141-152.

22. González, M.I.; Estévez, B. Participación, comunicación y negociación en conflictos ambientales: Energía eólica marina en el mar de Trafalgar (Participation, communication and negotiation in environmental conflicts: Offshore wind energy in the Trafalgar Sea). Arbor 2005, 715, 377-392. [CrossRef]

23. Muñóz, M.; Cruz, I.; Albesa, F.; Altobelli, F.; Condorí, M. Percepción social de la implementación de energía solar térmica al proceso de curado de tabaco (Social perception of the implementation of solar thermal energy in the tobacco curing process). In Proceedings of the XXXIX Reunión de Trabajo de la Asociación Argentina de Energías Renovables y Medio Ambiente (ASADES), Buenos Aires, Argentina, 25-28 October 2016.

24. Arenas-Aquino, Á.R.; Matsumoto-Kuwabara, Y.; Kleiche-Dray, M. Energía solar y marginación. Análisis de la percepción social sobre nuevas tecnologías para la articulación de una transición energética en el municipio de Nezahualcóyotl, México (Solar energy and marginalization. Analysis of social perception about new technologies for the articulation of an energy transition in the municipality of Nezahualcóyotl, Mexico). Rev. Int. Contam. Ambient. 2017, 3, 449-461.

25. Blackman, A.; Bannister, G.J. Community Pressure and Clean Technology in the Informal Sector: An Econometric Analysis of the Adoption of Propane by Traditional Mexican Brickmakers. J. Environ. Econ. Manag. 1998, 35, 1-21. [CrossRef]

26. Matos, Y.M.; Pasek, E.L.; Peña, M.L.; Briceño, M.V. Participación Ciudadana para una Educación Ambiental Sustentable (Citizen Participation for a Sustainable Environmental Education). Rev. Sci. 2018, 9, 233-255. [CrossRef]

27. Kim, S.; Jeong, S.H.; Hwang, Y. Predictors of pro-environmental behaviors of American and Korean students: The application of the theory of reasoned action and protection motivation theory. Sci. Commun. 2013, 35, 168-188. [CrossRef]

28. Untaru, E.-N.; Ispas, A.; Candrea, A.N.; Luca, M.; Epuran, G. Predictors of individuals' intention to conserve water in a lodging context: The application of an extended Theory of Reasoned Action. Int. J. Hosp. Manag. 2016, 59, 50-59. [CrossRef]

29. Jorgensen, B.S.; Martin, J.F.; Pearce, M.; Willis, E. Some difficulties and inconsistencies when using habit strength and reasoned action variables in models of metered household water conservation. J. Environ. Manag. 2013, 115, 124-135. [CrossRef]

30. Bamberg, S.; Rees, J.; Seebauer, S. Collective climate action: Determinants of participation intention in community-based pro-environmental initiatives. J. Environ. Psychol. 2015, 43, 155-165. [CrossRef] 
31. Vallerand, R.J.; Deshaies, P.; Cuerrier, J.P.; Pelletier, L.G.; Mongeau, C. Ajzen and Fishbein's theory of reasoned action as applied to moral behavior: A confirmatory analysis. J. Personal. Soc. Psychol. 1992, 62, 98. [CrossRef]

32. Sheppard, B.H.; Hartwick, J.; Warshaw, P.R. The Theory of Reasoned Action: A Meta-Analysis of Past Research with Recommendations for Modifications and Future Research. J. Consum. Res. 1988, 15, 325-343. [CrossRef]

33. Stern, P.C. Information, Incentives, and Proenvironmental Consumer Behavior. J. Consum. Policy 1999, 22, 461-478. [CrossRef]

34. Dietz, T.; Stern, P.C. Toward a theory of choice: Socially embedded preference construction. J. Socio-Econ. 1995, 24, 261-279. [CrossRef]

35. Stern, P.C.; Dietz, T.; Guagnano, G.A. The New Ecological Paradigm in Social-Psychological Context. Environ. Behav. 1995, 27, 723-743. [CrossRef]

36. Buela-Casal, G.; Sierra, J.C. Manual de Evaluación Psicológica: Fundamentos, Técnicas y Aplicaciones (Psychological Evaluation Manual: Foundations, Techniques and Applications); Siglo XXI de España: Madrid, Spain, 1997.

37. Escobar-Pérez, J.; Cuervo-Martínez, Á. Validez de contenido y juicio de expertos: Una aproximación a su utilización (Content validity and expert judgment: An approach to its use). Av. Med. 2008, 1, 27-36.

38. Burke, M.J.; Stephens, J.C. Political power and renewable energy futures: A critical review. Energy Res. Soc. Sci. 2018, 35, 78-93. [CrossRef]

39. Montero, I.; León, O.G. Sistema de clasificación del método en los informes de investigación en Psicología (Method classification system in research reports in Psychology). Int. J. Clin. Health Psychol. 2005, 5, 115-127.

40. Aiken, L.R. Content Validity and Reliability of Single Items or Questionnaires. Educ. Psychol. Meas. 1980, 40, 955-959. [CrossRef]

41. Aiken, L.R. Three Coefficients for Analyzing the Reliability and Validity of Ratings. Educ. Psychol. Meas. 1985, 45, 131-142. [CrossRef]

42. Cronbach, L.J. Coefficient alpha and the internal structure of tests. Psychometrika 1951, 16, 297-334. [CrossRef]

43. Cronbach, L.J.; Shavelson, R.J. My Current Thoughts on Coefficient Alpha and Successor Procedures. Educ. Psychol. Meas. 2004, 64, 391-418. [CrossRef]

44. Fernández-Gómez, E.; Martín-Salvador, A.; Luque-Vara, T.; Sánchez-Ojeda, M.A.; Navarro-Prado, S.; Enrique-Mirón, C. Content Validation through Expert Judgement of an Instrument on the Nutritional Knowledge, Beliefs, and Habits of Pregnant Women. Nutrients 2020, 12, 1136. [CrossRef] [PubMed]

45. Penfield, R.D.; Giacobbi, P.R. Applying a Score Confidence Interval to Aiken's Item Content-Relevance Index. Meas. Phys. Educ. Exerc. Sci. 2004, 4, 213-225. [CrossRef]

46. Cicchetti, D.V. Guidelines, criteria, and rules of thumb for evaluating normed and standardized assessment instruments in psychology. Psychol. Assess. 1994, 6, 284-290. [CrossRef]

47. De Winter, J.C.; Dodou, D. Factor recovery by principal axis factoring and maximum likelihood factor analysis as a function of factor pattern and sample size. J. Appl. Stat. 2012, 39, 695-710. [CrossRef]

48. Hair, J.F.; Black, W.C.; Babin, B.J.; Anderson, R.E. Multivariate Data Analysis, 7th ed.; Prentice Hall: Upper Saddle River, NJ, USA, 2010.

49. Berenguer, J.M.; Corraliza, J.A. Preocupación ambiental y comportamientos ecológicos (Environmental concern and ecological behavior). Psicothema 2000, 3, 325-329.

50. López, M.C.; Hinojosa, E.F. Construction and validation of a questionnaire to study future teachers' beliefs about cultural diversity. Int. J. Incl. Educ. 2016, 5, 503-519. [CrossRef]

51. Brownstein, N.C.; Louis, T.A.; O'Hagan, A.; Pendergast, J. The Role of Expert Judgment in Statistical Inference and Evidence-Based Decision-Making. Am. Stat. 2019, 73, 56-68. [CrossRef]

52. Kimberlin, C.L.; Winterstein, A.G. Validity and reliability of measurement instruments used in research. Am. J. Heal. Pharm. 2008, 65, 2276-2284. [CrossRef]

53. Mills, A.; Butt, J.; Maynard, I.; Harwood, C. Identifying factors perceived to influence the development of elite youth football academy players. J. Sports Sci. 2012, 30, 1593-1604. [CrossRef]

54. Mendoza, J.; Garza, J.B. La medición en el proceso de investigación científica: Evaluación de validez de contenido y confiabilidad (Measurement in the Scientific Research Process: Assessing Content Validity and Reliability). Innov. Neg. 2009, 11, 17-32.

55. Carvajal, A.; Centeno, C.; Watson, R.; Martínez, M.; Sanz Rubiales, Á. Cómo validar un instrumento de medida de la salud? (How to validate a health measurement instrument?). In Anales del Sistema Sanitario de Navarra; Gobierno de Navarra, Departamento de Salud: Navarra, Spain, 2011; Volume 34, pp. 63-72.

56. Córdoba, R.L. Recomendaciones sobre los procedimientos de construcción y validación de instrumentos y escalas de medición en la psicología de la salud (Recommendations on the construction and validation procedures of instruments and measurement scales in health psychology). Psicol. Salud 2017, 27, 5-18.

57. Haynes, S.N.; Richard, D.; Kubany, E.S. Content validity in psychological assessment: A functional approach to concepts and methods. Psychol. Assess. 1995, 7, 238. [CrossRef]

58. McFarland, G.K.; Polit, D.F.; Hungler, B.P. Nursing Research: Principles and Methods; Lippincott Williams \& Wilkins: Philadelphia, PA, USA, 1999.

59. Soriano, A.M. Diseño y validación de instrumentos de medición (Design and validation of measurement instruments). Diálogos 2014, 14, 19-40. 
60. Winer, M.; Welch, S.; Comer, J.C. Quantitative Methods for Public Administration: Techniques and Applications. J. Policy Anal. Manag. 1983, 2, 655. [CrossRef]

61. Martínez, J.R. Los tamaños de las muestras en encuestas de las ciencias sociales y su repercusión en la generación del conocimiento (Sample sizes in social science surveys and their impact on knowledge generation). Innov. Neg. 2017, 11, $235-268$.

62. Leyva Barajas, Y.E. Una reseña sobre la validez de constructo de pruebas referidas a criterio (A review of the construct validity of criterion-referenced tests). Perf. Educ. 2011, 33, 131-154.

63. Fernández, R.G.; Mozo, A.G.; Martínez, J.P.; Muñoz, A.M. Percepciones y actitudes sobre la energía sostenible en alumnos de Educación Secundaria y propuesta de actividades (Perceptions and attitudes about sustainable energy in Secondary Education students and proposed activities). Rev. Electrónica Medio Ambiente 2017, 18, 79-97.

64. Armijo, G.; Roubelat, L.; Jara, P.; Whitman, C. Pobreza Energética: Perspectiva Desde La Intervención Urbana, Edificación y el Medio Ambiente (Energy Poverty: Perspective from Urban Intervention, Building and the Environment). Cuid. Arquit. $2016,152$. Available online: http:/ / orca.cf.ac.uk/90886/ (accessed on 21 February 2021).

65. Halkos, G.; Skouloudis, A. National CSR and institutional conditions: An exploratory study. J. Clean. Prod. 2016, 139, 1150-1156. [CrossRef] 